\title{
And then two came along at once: inter- state cooperation on core crimes, the ILC and the group of core states
}

Article

Accepted Version

Bisset, A. (2020) And then two came along at once: inter-state cooperation on core crimes, the ILC and the group of core states. International Criminal Law Review, 20 (3). pp. 551-586. ISSN 1571-8123 doi: https://doi.org/10.1163/1571812302003001 Available at https://centaur.reading.ac.uk/89466/

It is advisable to refer to the publisher's version if you intend to cite from the work. See Guidance on citing.

To link to this article DOI: http://dx.doi.org/10.1163/15718123-02003001

Publisher: Brill

All outputs in CentAUR are protected by Intellectual Property Rights law, including copyright law. Copyright and IPR is retained by the creators or other copyright holders. Terms and conditions for use of this material are defined in the End User Agreement.

$\underline{\text { www.reading.ac.uk/centaur }}$

\section{CentAUR}


Central Archive at the University of Reading

Reading's research outputs online 


\title{
And then two came along at once: Inter-State Cooperation on Core Crimes, the ILC and the Group of Core States
}

\begin{abstract}
Despite their fundamental importance in the effective prosecution of international crimes, inter-state judicial cooperation regimes have long been overlooked. However, two new initiatives have recently emerged. The first is the International Law Commission's Draft Articles on Crimes Against Humanity (Draft Articles), which aims to create a global convention on prevention, punishment and inter-State cooperation with respect to crimes against humanity. The second initiative, the Mutual Legal Assistance Treaty for core crimes (MLA Treaty), is wider in scope. It encompasses genocide, war crimes and crimes against humanity and seeks the conclusion of a multilateral cooperation treaty to enable the effective provision of mutual legal assistance and extradition of suspects in relation to these crimes. The aim of this article is to critically assess the merits and shortcomings of these two initiatives in the effort to enhance inter-state cooperation in the prosecution of international crimes and their abilities to remedy current problems.
\end{abstract}

\section{Keywords}

Inter-state cooperation, prosecution, international crimes 


\section{Introduction}

Since the creation of the International Criminal Court (ICC), international hopes and expectations for the prosecution of international crimes ${ }^{1}$ have centred on the ICC. Yet it is not possible, either in theory or practice, for the Court to pursue prosecutions in all instances. The ICC was established as a Court of last resort, which would step in when national courts are unable or unwilling to carry out criminal trials. ${ }^{2}$ Thus, even if it were practically possible, the Court should not be responsible for prosecuting all instances of international crimes. Moreover, the ICC Statute is not universally ratified, the Court does not have jurisdiction over all cases without Security Council referral $^{3}$ or state agreement, ${ }^{4}$ and even where it does have potential jurisdiction, the Court has limited resources that mean it cannot take on all cases. ${ }^{5}$

Recent failures by the Court to illicit from states the necessary assistance for the effective prosecution of international crimes has refocused attention on the crucial

\footnotetext{
${ }^{1}$ International crimes are defined here as genocide, crimes against humanity and war crimes, as these are the crimes that fall within the jurisdiction of the permanent international criminal court. Arts 6,7 and 8, ICC Statute.

${ }^{2}$ Art 17, ICC Statute. See Mohammed El Zeidy, “The Principle of Complementarity: A New Principle to Implement International Criminal Law” 23 Michigan Journal of International Law (2001-2002) 869-955.

${ }^{3}$ Art 13(b) ICC Statute.

${ }^{4}$ Art 12(3) ICC Statute.

${ }^{5}$ International Criminal Court, Office of the Prosecutor, Policy Paper on Case Selection and Prioritization, 15 September 2016, paras. 12 and 49.
} 
role of state cooperation in conducting trials of those responsible. ${ }^{6}$ Problems at the Court, in conjunction with the impunity gap created by regional non-ratification of the ICC Statute in the Middle East and Asia, ${ }^{7}$ the threat of African Union withdrawal, ${ }^{8}$ and the lack of referral consensus at the UN Security Council ${ }^{9}$ have brought fresh scrutiny to the role that national courts can play. The notion that the best prospects for prosecution lie at national levels is not new. Indeed, the ICC is premised on the principle of complementarity, ${ }^{10}$ which envisages national courts as having primary responsibility for the prosecution of international crimes. However, the ICC Statute itself only regulates cooperation between states and the Court. ${ }^{11}$ It provides no horizontal cooperation regime to govern the provision of judicial assistance or extradition of suspects between states.

\footnotetext{
${ }^{6}$ For a summary of the cooperation cases at the ICC see Annalisa Ciampi, 'Legal Rules, Policy Choices and Political Realities in the Functioning of the Cooperation Regime of the International Criminal Court', in Olympia Bekou and Daley J. Birkett (eds.), Cooperation and the International Criminal Court: Perspectives from Theory and Practice, (Brill Nijhoff, Leiden, 2016) pp. 7-57.
}

${ }^{7}$ A list of states parties can be found on the ICC's website, www.icc-cpi.int, accessed 17 July 2018.

${ }^{8}$ African Union, Withdrawal Strategy Document, (Addis Ababa, Ethiopia, 12 January 2017); Gino Naldi and Konstantinos Magliveras, 'The International Criminal Court and the African Union: A Problematic Relationship', in Charles Chernor Jalloh and Ilias Bantekas (eds.), The International Criminal Court and Africa, (Oxford University Press, Oxford, 2017) pp. 111-137.

${ }^{9}$ Kirsten Bowman, 'The International Criminal Court and the Security Council: The Power of Politics and the Undermining of Justice' in Joanna Nicholson (ed.), Strengthening the Validity of International Criminal Tribunals, (Brill, Leiden, 2017) pp. 245-270; Alexandre Skander Galant, UN Security Council Referrals to the International Criminal Court: Legal Nature, Effects and Limits, (Brill, Leiden, 2018).

${ }^{10}$ Arts 1 and 17, ICC Statute.

${ }^{11}$ Part 9, ICC Statute. 
The political instability and infrastructure vulnerability that frequently accompanies the commission of international crimes means that the state of territoriality will often be unable to carry out criminal trials. ${ }^{12}$ Traditionally, bystander states were, and indeed may still be, unwilling to pursue prosecutions for diplomatic reasons. ${ }^{13}$ Indications are, however, that this traditional position may have begun to alter following the creation of the ICC and the efforts of states parties to enact domestic legislation implementing their obligations under the Statute. Some of that legislation has extended jurisdictional competence and authorises the prosecution of international crimes wherever they occur. ${ }^{14}$ Yet even where they are willing, inadequate legal cooperation regimes can thwart efforts to prosecute by making it difficult to gain information and evidence, access to witnesses and custody of suspects. ${ }^{15}$

${ }^{12}$ Alex Boraine, 'Truth and Reconciliation in South Africa: The Third Way' in Robert I. Rotberg and
Dennis Thompson (eds.), Truth v. Justice: The Morality of Truth Commissions, (Princeton University Press, Princeton, 2000) pp. 141-3; Jorge S Correa, 'Dealing with Part Human Rights Violations: The Chilean Case After Dictatorship', 67 Notre Dame Law Review (1992) 1455-1485; Mark Vassalo, 'Truth and Reconciliation Commissions: General Considerations and a Critical Comparison of the Commissions of Chile and El Salvador' 33 University of Miami Inter-American Law Review (2002) 153-182, pp. 159-60.

${ }^{13}$ Luc Reydams, Universal Jurisdiction: International and Municipal Legal Perspectives (Oxford University Press, Oxford, 2003); Wolfgang Kalek, 'From Pinochet to Rumsfeld: Universal Jurisdiction in Europe 1998-2008', 30 Michigan Journal of International Law (2009) 927-935.

${ }^{14}$ The ICC's Legal Tools database contains details of all national implementing legislation. See www.legal-tools.org, accessed 17 July 2018.

${ }^{15}$ For an overview of past cases see Ward Ferdinandusse, 'Improving Inter-State Cooperation for the National Prosecution of International Crimes: Towards a New Treaty?' 18(15) ASIL Insights, 21 July 2014. 
There are currently no international or regional treaties focussed on inter-state cooperation in the prosecution of international crimes. The Genocide Convention and the Geneva Conventions and their Additional Protocols contain only the most basic guidance on how states ought to cooperate and, at that, only in relation to genocide and war crimes committed in international armed conflict. ${ }^{16}$ Cooperation on crimes against humanity, which are not the subject of any specific treaty, is not regulated. Neither is that on war crimes committed in non-international armed conflict. The provision of assistance is therefore dependent upon existing methods of inter-state cooperation in international law. However, existing legal regimes, where they apply between states, were not designed with the aim of facilitating cooperation around international crimes, and, contain grounds for refusing assistance which are, arguably, not appropriate in this context. ${ }^{17}$ It is clear that international criminal law must look for new ways to maintain the impetus for effectively prosecuting international crimes and for improving cooperation in investigations and prosecutions.

To that end, two new initiatives have emerged. The first is the International Law Commission's Draft Articles on Crimes Against Humanity (Draft Articles), ${ }^{18}$ which aims to create a global convention on prevention, punishment and inter-State

\footnotetext{
${ }^{16}$ See Section 2 below.

${ }^{17}$ A Legal Gap? Getting the Evidence where it can be found: Investigating and prosecuting international Crimes, The Hague Institute for Global Justice, 22 November 2011; The Global Fight Against Impunity: The International Criminal Court and Dutch Foreign Policy, 7 August 2015.

${ }^{18}$ International Law Commission, Text and titles of the draft preamble, the draft articles and the draft annex provisionally adopted by the Drafting Committee on second reading, Prevention and punishment of crimes against humanity, A/CN.4/L.935, 15 May 2019.
} 
cooperation with respect to crimes against humanity. ${ }^{19}$ The second initiative, originally proposed by Belgium, Slovenia and the Netherlands, is broader in scope. The Mutual Legal Assistance Treaty for core crimes (MLA Treaty) ${ }^{20}$ encompasses genocide, war crimes and crimes against humanity and seeks the conclusion of a multilateral cooperation treaty to enable the effective provision of mutual legal assistance and extradition of suspects in relation to these crimes. Despite their fundamental importance in the effective prosecution of international crimes, interstate judicial cooperation regimes, including these initiatives, have received little academic attention. ${ }^{21}$ The aims of this article are to: (1) critically compare and contrast the extradition and mutual legal assistance regimes of these two initiatives; (2) analyse their respective merits and shortcomings in the effort to enhance interstate cooperation in the prosecution of international crimes; and (3) and assess their

\footnotetext{
${ }^{19}$ International Law Commission, First Report on Crimes Against Humanity by Sean D. Murphy, Special Rapporteur, A/CN.4/680, 17 February 2015, para 12.

${ }^{20}$ Convention on International Cooperation in the Investigation and Prosecution of the Crime of Genocide, Crimes Against Humanity and War Crimes, annexed to International Law Commission, Crimes Against Humanity, Additional comments and observation received from Governments, international organizations and others, Addendum, A/CN.4/726/Add.1, 28 March 2019, Annex II. See too Joint Initiative for Better International Cooperation in the Domestic Prosecution of International Crimes, Explanatory Note, 2015.

${ }^{21}$ Notable exceptions include: Dire Tladi, 'A Horizontal Treaty on Cooperation in International Criminal Matters: The next step for the evolution of a comprehensive international criminal justice system?' 29 South African Public Law (2014) 368-387; Sean D. Murphy, 'New Mechanisms for Punishing Atrocities in Non-International Armed Conflicts', 16 Melbourne Journal of International Law (2015) 299-310; M. Cherif Bassiouni, 'Crimes Against Humanity: The Case for a Specialized Convention', 9(4) Washington University Global Studies Law Review (2010) 575-594.
} 
abilities to remedy current problems. It will argue that neither instrument possesses the requisite innovation to significantly reform international cooperation in this area.

The article will begin by considering current cooperation regimes and the difficulties encountered in using them to facilitate international crimes prosecutions. It will then analyse the cooperation proposals within the ILC Draft Articles and the MLA Treaty and critically assess the two approaches. The article will demonstrate that the envisaged cooperation regimes are not particularly different - nor particularly inventive - but that the ILC sole focus on crimes against humanity leaves the impunity gap unplugged, as it does nothing to improve the inadequate existing regimes on genocide and war crimes. The article will conclude that if the prospects for effective prosecution of international crimes are to be enhanced, states must think more innovatively, break away from traditional models of cooperation and put national interests aside in the quest to secure international justice for the most serious crimes.

\section{Existing Regimes and the Need for Reform}

The importance of state cooperation in the prosecution of international crimes cannot be overstated. The nature of international crimes means that regardless of the forum in which they are to be prosecuted, cooperation between states or between states and institutions will be essential if trials are to be successful. In the aftermath of international crimes, large numbers of victims, witnesses and perpetrators tend to be displaced and located across different countries. The information and evidence necessary to prove international crimes, such as that related to military and security 
operations, the policies of governments and other actors, and the actual commission of acts of genocide, crimes against humanity and war crimes are likely to be held by a range of national and international institutions. The prosecuting body, whether it is a domestic court or international tribunal, will be dependent on the assistance of other states and entities to collect evidence, apprehend suspects, protect witnesses and track and seize assets belonging to alleged perpetrators. ${ }^{22}$ Without cooperation regimes these tasks cannot be completed effectively and international crimes cannot be successfully prosecuted.

\subsection{Cooperation with International Courts and Tribunals}

Much attention has been paid to the work of international courts in the prosecution of international crimes. The crucial role that states play in facilitating and bolstering fact-finding and transfer of individuals needed to carry out trials within international courts seems sometimes to be overlooked. ${ }^{23}$ The importance of cooperation is reflected in the statutes for the ICTY and ICTR and their Rules of Procedure and Evidence. ${ }^{24}$ Both contain provisions obligating states to cooperate with the Tribunals across a range of pre and post-trial activities ${ }^{25}$ and to comply with requests for

\footnotetext{
${ }^{22}$ Pascal Turlan, 'The International Criminal Court Cooperation Regime - A Practical Perspective from the Office of the Prosecutor' in Bekou and Birkett, supra note 6, p.58-79.

${ }^{23}$ Antonio Cassese 'On the Current Trends towards Criminal Prosecution and Punishment of Breaches of International Humanitarian Law' 9 European Journal of International Law (1998) 2-17.

${ }^{24}$ Dagmar Stroh, 'State Cooperation with the International Criminal Tribunals for the former Yugoslavia and Rwanda', 5 Max Planck Yearbook of United Nations Law (2001) 249-283.

${ }^{25}$ ICTY RoPE R54-61; ICTR RoPE R54-61.
} 
assistance or orders issued by the Trial Chambers. ${ }^{26}$ As a result of their establishment under UN Security Council Chapter VII Resolutions, ${ }^{27}$ and the near universal adherence of states to the UN Charter, the obligations to cooperate apply to almost all states. Although states have not always fully complied with the requests and orders of the Tribunals, ${ }^{28}$ in legal terms there are provisions in place to ensure that the ad hoc Tribunals can access the information and evidence needed to compile cases and to gain custody of individuals to stand trial. However, the cooperation arrangements within the statutes of the ICTY and ICTR are of no assistance when it comes to interstate cooperation as they pertain only to the relationship between states and the Tribunals and only to crimes committed during the conflicts in the former Yugoslavia and Rwanda.

Cooperation obligations were not included within the statutes of the hybrid courts, often impeding the ability of these courts to fulfil their mandates. ${ }^{29}$ The significance of cooperation is recognised within the ICC Statute, ${ }^{30}$ where, although it has not

\footnotetext{
${ }^{26}$ Art 29 ICTY Statute; Art 28 ICTR Statute.

${ }^{27}$ UNSC Res 827, 25 May 1993, S/RES/827 (1993) (ICTY); UNSC Res 955, 8 November 1994,
} S/RES/994 (1994) (ICTR).

${ }^{28}$ Victor Peskin, International Justice in Rwanda and the Balkans: Virtual Trials and the Struggle for State Cooperation, (Cambridge University Press, Cambridge, 2008).

${ }^{29}$ Megan Hirst and Howard Varney, Justice Abandoned? An Assessment of the Serious Crimes Process in East Timor, International Center for Transitional Justice, June 2005; Shakiratu Sanusi, 'SCSL Practice on Cooperation with the Host State and Third States: A Contribution to Africa and International Criminal Justice', in Charles Chernor Jalloh (ed.) The Sierra Leone Special Court and Its Legacy, (Cambridge University Press, Cambridge, 2014)), 469-480.

${ }^{30}$ Phakiso Mochochoko, 'International Cooperation and Judicial Assistance' in Roy S. Lee (ed) The International Criminal Court: The Making of the Rome Statute - Issues, Negotiation, Results, (Kluwer 
always operated effectively to enable the Court to pursue criminal trials of those indicted, ${ }^{31}$ it occupies one of the most extensively regulated elements of the ICC regime. ${ }^{32}$ States Parties are under a general obligation to 'cooperate fully with the Court in its investigation and prosecution of the crimes' within the Statute ${ }^{33}$ and are to provide assistance in two main areas: arrest and surrender ${ }^{34}$ and the provision of other forms of assistance that the Court may require, which are listed at length. ${ }^{35}$ States parties are to 'ensure that that there are procedures available under their national law for all the forms of cooperation' specified in Part IX of the Statute. ${ }^{36}$ Reservations are not permitted. ${ }^{37}$ The ICC can, additionally, receive cooperation from non-States Parties where an agreement to that effect is entered into ${ }^{38}$ and from international organisations, such as the UN. ${ }^{39}$ Frustratingly, despite the central place of national prosecution within the ICC complementarity regime, the ICC Statute only regulates the cooperation relationship between the Court and states. It does nothing to facilitate cooperation between states in the event that trials are pursued at national levels.

Law International, The Hague,1999), pp. 305; Goran Sluiter, 'The Surrender of War Criminals to the International Criminal Court', 25 Loyola of Los Angeles International and Comparative Law Review (2003) 605-651.

${ }^{31}$ Ciampi, supra note 6.

${ }^{32}$ Part IX, ICC Statute.

${ }^{33}$ Art 86 ICC Statute.

${ }^{34}$ Arts 89-92 and 101-102, ICC Statute.

${ }^{35} \operatorname{Art} 93(1)(a)-(1)$.

${ }^{36}$ Art 88 , ICC Statute.

${ }^{37}$ Art 120 ICC Statute.

${ }^{38}$ Art 12(3) ICC Statute.

${ }^{39}$ Negotiated Relationship Agreement between the International Criminal Court and the United Nations (ICC-ASP/3/Res.1) 4 October 2004. 
Where this is the case, states are dependent on existing methods of cooperation under international law.

\subsection{Cooperation Between States}

\subsubsection{Obligations Relating to International Crimes}

Existing international legal frameworks regulating state cooperation in the prosecution of international crimes are haphazard, underdeveloped and spread across a multiplicity of instruments. Indeed, the ICC Statute apart, state obligations relating to the prosecution of international crimes are generally fragmented and lacking in clarity. Only a small number of international crimes incur an unequivocal demand for prosecution under treaty. ${ }^{40}$ Many of the most serious crimes are not the subject of

\footnotetext{
${ }^{40}$ UN Convention on the Prevention and Punishment of the Crime of Genocide, 9 December 1948, 78 UNTS 227, Art. 6 .

${ }^{40}$ Geneva Convention I for the Amelioration of the Condition of the Wounded and Sick in Armed Forces in the Field, 12 August 1949, 75 UNTS 31, Art. 49; Geneva Convention II for the Amelioration of the Condition of Wounded, Sick and Shipwrecked Members of Armed Forces at Sea, 12 August 1949, 75 UNTS 85, Art. 50; Geneva Convention III Relative to the Treatment of Prisoners of War, 12 August 1949, 75 UNTS 135, Art. 129; Geneva Convention IV Relative to the Protection of Civilian Persons in Time of War, 12 August 1949, 75 UNTS 287, Art. 146; International Convention on the Suppression and Punishment of the Crime of Apartheid, 30 November 1973, 1015 UNTS 243, Art. 4(b); UN Convention Against Torture and Other Cruel, Inhuman or Degrading Treatment or Punishment, 10 December 1984, 1465 UNTS 85, Arts. 4(2) and 7; International Convention for the Protection of All Persons from Enforced Disappearance, New York, 20 December 2006, General
} 
treaties that impose duties to prosecute and the extent to which there is a customary obligation to prosecute international crimes is contentious. ${ }^{41}$ While the majority of states and authoritative commentators agree that states have a right to prosecute, ${ }^{42}$ there is not the same consensus on the existence or scope of any customary duty to prosecute. Some argue that customary law recognises a duty to prosecute for states in which an international crime is committed. ${ }^{43}$ Others contend that there is only an Assembly Resolution 61/177; Inter-American Convention on the Forced Disappearance of Persons, Belém, Brazil, 9 June 1994, (1994) 33 ILM 1529.

41 Some have argued in favour of a customary duty to prosecute. See M. Cherif Bassiouni, 'International Crimes: Jus Cogens and Obligatio Erga Omnes', (1996) 59 Law and Contemporary Problems 63-74, at 67; Miles M. Jackson, 'The Customary International Law Duty to Prosecute Crimes Against Humanity: A New Framework', 16 Tulane Journal of International and Comparative Law (2007) 117-156; Dianne Orentlicher, 'Settling Accounts: The Duty to Prosecute Human Rights Violations of a Prior Regime', 100 Yale Law Journal (1991) 2537-2615. Others are dubious. See Michael P. Scharf, 'The Letter of the Law: The Scope of the International Legal Obligation to Prosecute Human Rights Crimes', 59 Law and Contemporary Problems (1996) 41-62; Roman Boed, 'The Effect of a Domestic Amnesty on the Ability of Foreign States to Prosecute Alleged Perpetrators of Serious Human Rights Violations', 33 Cornell International Law Journal (2000) 297-329; Ben Chigara, Amnesty in International Law: The Legality under International Law of National Amnesty Laws, (Pearson Education Ltd., Harlow, Essex: 2002).

${ }^{42}$ Gerhard Werle, Principles of International Criminal Law, (2 ${ }^{\text {nd }}$. edn.) (T.M.C. Asser Press, The Hague: 2009), pp. 29, 69-70; Ian Brownlie, Principles of Public International Law, (7 $7^{\text {th }}$ edn.), (Oxford: Oxford University Press, 2008), pp. 589-593; Antonio Cassese, International Criminal Law, (2 ${ }^{\text {nd }}$ edn.) (Oxford: Oxford University Press, 2008), pp.12.

${ }^{43}$ Claus Kress, 'War Crimes Committed in Non-International Armed Conflict and the Emerging System of International Criminal Justice', 30 Israel Yearbook on Human Rights (2001) 103-177, p.163; Naomi Roht-Arriaza, 'Amnesty and the International Criminal Court', in Dinah Shelton (ed.), International Crimes, Peace and Human Rights: The Role of the International Criminal Courts, (Transnational Publishers, New York, 2000), Ch. 8; Christian Tomuschat, 'The Duty to Prosecute 
emerging customary duty to prosecute international crimes based on territoriality and, to some extent, nationality jurisdiction. ${ }^{44}$ Others still submit that the obligation aut dedere aut judicare has crystalized, or is in the process of crystalizing, into a rule of customary law for the core crimes proscribed by jus cogens. ${ }^{45}$

Notwithstanding the absence of treaty obligations to prosecute, and disputes around the status of customary duties, the commission of international crimes is likely to result in international pressure to prosecute through some means, again emphasizing the importance of adequate cooperation regimes. Yet there is no general international legal obligation on states to provide judicial assistance to others seeking to prosecute international crimes. ${ }^{46}$ There are currently no international or regional treaties focussed on inter-state cooperation relating to alleged perpetrators of crimes against humanity or war crimes committed in non-international armed conflict. The few

International Crimes Committed by Individuals', in Hans-Joachim Cremer et al (eds.), Tradition und Weltoffenheit des Rechts: Festschrift fur Helmut Steinberge, (Springer, Berlin, 2002) pp. 315-351, 342; John Dugard, 'Possible Conflicts of Jurisdiction with Truth Commissions', in Antonio Cassese, Paulo Gaeta and John Jones, (eds.), The Rome Statute of the International Criminal Court: A Commentary, 2 vols., (Oxford University Press, Oxford, 2002), vol. 2, 693-704, 696-69.

${ }^{44}$ Anja Seibert-Fohr, Prosecuting Serious Human Rights Violations, (Oxford University Press, Oxford, 2009), Ch. 7; Darryl Robinson, 'Serving the Interests of Justice: Amnesties, Truth Commissions and the International Criminal Court', 14 EJIL (2003) 481-505.

${ }^{45}$ Kriangsak Kittichaisaree, The Obligation to Extradite or Prosecute, (Oxford University Press, Oxford, 2018), p.165; Claire Mitchell, Aut Dedere, aut Judicare: The Extradite or Prosecute Clause in International Law, (Graduate Institute Publications, Genenva, 2009), p. 30

${ }^{46}$ Bruce Broomhall, International Justice and the International Criminal Court: Between State Sovereignty and the Rule of Law, (Oxford University Press, Oxford, 2003), p.119-123. 
existing provisions pertaining to cooperation on genocide and war crimes committed during international armed conflict have been described as "rudimentary" in nature. ${ }^{47}$

The simplistic nature of existing arrangements can be seen in the Genocide Convention. ${ }^{48}$ It requires states parties to ensure the availability of adequate penalties under national law where the crime of genocide ${ }^{49}$ is committed. ${ }^{50}$ However, obligations relating to prosecution are thin, requiring only the establishment of territorial jurisdiction, and giving brief mention to the potential jurisdiction of any international tribunal that might be created. ${ }^{51}$ The Convention states that genocide shall not be considered a political offence for the purposes of extradition, ${ }^{52}$ but provides no framework for conducting extradition between states. Instead, states parties are to 'grant extradition in accordance with their laws and treaties in force' ${ }^{53}$ Mutual legal assistance is not considered. The cooperation clauses of the Convention, or lack thereof, are thus considered to create something of a legal vacuum in the effort to prosecute genocide..$^{54}$

\footnotetext{
${ }^{47}$ Kittichaisaree, supra note 45, p.165.

${ }^{48}$ Convention on the Prevention and Punishment of the Crime of Genocide, 9 December 1948, 78 UNTS 277.

${ }^{49}$ Defined in Articles II and III.

${ }^{50}$ Article V.

${ }^{51}$ Article VI.

${ }^{52}$ Article VII.

${ }^{53} \mathrm{Ibid}$.

${ }^{54}$ A Legal Gap? supra note 17, p.23.
} 
In relation to war crimes, the Geneva Conventions of $1949^{55}$ contain provisions, in a common article, ${ }^{56}$ aimed at the prosecution of persons accused of having committed 'grave breaches' ${ }^{57}$ of the Conventions. High Contracting Parties are required to enact legislation to provide effective penal sanctions for persons committing or ordering any of the grave breaches. They are obligated to bring such persons, regardless of nationality, before their own courts, or if they prefer to 'hand such persons over for trial to another High Contracting Party'. Yet, despite the inclusion of the aut dedere aut judicare mechanism, the Geneva Conventions do not provide a basis for extradition or the provision of mutual legal assistance. Only Additional Protocol I, applicable solely to crimes committed in international armed conflict, contains provisions for mutual legal assistance, stating that High Contracting Parties shall provide one another the greatest measure of assistance in connection with criminal proceedings brought in respect of grave beaches or of the Protocol. However, when it comes to extradition, the Protocol is weak, requiring only that "when circumstances permit, the High Contracting Parties shall cooperate in the matter of extradition', giving 'due consideration to the request of the state in whose territory the alleged offence has occurred' ${ }^{58}$ Like those of the Genocide Convention, these provisions are vague. The actual processes of mutual legal assistance and extradition remain subject to whatever national laws and treaties the states concerned have in place and requests

\footnotetext{
55 Supra note 52.

${ }^{56}$ Geneva Convention I, art. 49; Geneva Convention II, art. 50; Geneva Convention III, art. 129; Geneva Convention IV, art. 146.

${ }^{57}$ Geneva Convention I, Art 50; Geneva Convention II, Art 51; Geneva Convention III, Art 130; Geneva Convention IV, Art 147.

${ }^{58}$ Protocol Additional to the Geneva Conventions of 12 August 1949, and Relating to the Protection of Victims of International Armed Conflicts (Protocol I) 1125 UNTS 3, Article 88(2).
} 
for assistance in relation to the most serious international crimes remain open to refusal on traditional grounds, such as the political offence exception. ${ }^{59}$

The International Law Commission points, additionally, to the potential utility of Conventions that deal with specific crimes against humanity, ${ }^{60}$ such as torture, ${ }^{61}$ enforced disappearance ${ }^{62}$ and apartheid. ${ }^{63}$ It is true that these Conventions contain obligations related to extradition and the provision of judicial assistance, and that they could be relevant in situations where the crimes that they regulate are committed on a widespread or systematic basis against civilian populations. However, this is a fragmented method of facilitating judicial cooperation. These Conventions cover only a small number of the different crimes against humanity meaning that for the others there is no specific treaty regime enabling cooperation in their prosecution.

In short, international law currently lacks a comprehensive treaty regulating how states should cooperate in the prosecution of international crimes. Even where interstate cooperation is mentioned within treaties pertaining to international crimes, such

\footnotetext{
${ }^{59}$ Commentary on the Additional Protocols of 8 June 1977 to the Geneva Conventions of 12 August
} 1949, Commentary to Additional Protocol I, International Committee of the Red Cross, 1987, para 3580.

${ }^{60}$ International Law Commission, First Report on Crimes Against Humanity, supra note 19, paras. 73 77.

${ }^{61}$ Convention Against Torture, supra note 40, Arts 4(2) and 7.

${ }^{62}$ International Convention for the Protection of all Persons from Enforced Disappearance, supra note 40, Arts 4 and 9. See also Inter-American Convention on the Forced Disappearance of Persons, Belem, Brazil, 9 June 1994, (1994) 3 International Legal Materials 1529, Arts III and VI.

${ }^{63}$ International Convention on the Suppression and Punishment of the Crime of Apartheid, supra note 40, Art 4(b) 
as in the Genocide Convention and the Geneva Conventions and Additional Protocols, they direct states to their existing, general mutual legal assistance and extradition treaties, rather than creating regimes aimed at facilitating cooperation in the unique circumstances of international crimes. ${ }^{64}$

\subsubsection{State Practice in Prosecuting International Crimes}

There are a large number of international, regional and bilateral treaties and arrangements that regulate the provision of mutual legal assistance and extradition between states in criminal matters. ${ }^{65}$ Yet for a range of reasons they have not proven effective in facilitating cooperation between states in relation to international crimes. At the most basic level, no state has agreements in place with all others. Where there is no treaty agreement between states, practice shows that the provision of assistance is at best extremely slow and more likely non-existent. Many states require a legal basis for the provision of assistance and most are more likely to cooperate where they

\footnotetext{
${ }^{64}$ One notable regional instrument in this field is the Protocol for the Prevention and the Punishment of the Crimes of Genocide, War Crimes and Crimes against Humanity and all forms of Discrimination 2006, adopted at the International Conference on the Great Lakes Region, 26 November 2006, which aims to strengthen regional and international cooperation in relation to international crimes (Preamble, para. 5.). It too, however, is light on the technicalities of extradition and provides no framework for mutual legal assistance.

${ }^{65}$ M. Cherif Bassiouni (ed.), International Criminal Law, Multilateral and Bilateral Enforcement Mechanisms, vol. II, 3rd ed., (Martinus Nijhoff, Leiden, 2008); David A. Sadoff, Bringing International Fugitives to Justice: Extradition and its Alternatives, (Cambridge University Press, Cambridge, 2016).
} 
have a legal obligation to do so. ${ }^{66}$ Many existing agreements were concluded at a time when there was little experience of prosecuting international crimes and therefore do not reflect the complex procedural cooperation that has since been proved necessary to bring such crimes to trial. ${ }^{67}$ International treaties which do contain more modern cooperation arrangements, such as the UN Convention Against Transnational Organised Crime (UNTOC) ${ }^{68}$ and the UN Convention Against Corruption (UNCAC), ${ }^{69}$ are primarily concerned with crimes of corruption and those of a transnational, organised nature, rather than international human rights crimes. These instruments do not adapt easily to accommodate international crimes within the parameters of their definitions. Even where agreements are in place, mutual legal assistance and extradition treaties traditionally include a range of flexible and nebulous grounds upon which requests for assistance can be denied. ${ }^{70}$

In practice, the combination of the lack of relevant agreements between states and the manipulation of grounds for refusal where agreements are in place, have thwarted efforts by third states to prosecute international crimes. In 1974, Bolivia refused a French request for extradition of Klaus Barbie who had been convicted in absentia in France for war crimes committed during the Second World War on the basis that

\footnotetext{
${ }^{66}$ The Global Fight Against Impunity, supra note 17, p.46

${ }^{67}$ A Legal Gap, supra note 17, p.31.

${ }^{68}$ United Nations Convention Against Transnational Organized Crime, A/Res/55/25, 15 November 2000.

${ }^{69}$ United Nations Convention Against Corruption 2003, 2349 UNTS 41.

70 These will be discussed below.
} 
there was no applicable extradition treaty between the two states. ${ }^{71}$ Ethiopia failed to gain custody of Mengistu in order to try him for genocide as neither Zimbabwe or South Africa would extradite in the absence of an extradition treaty. ${ }^{72}$ In 2002 , Indonesia refused to extradite officials suspected of crimes against humanity to East Timor because there was no extradition treaty in place. ${ }^{73}$ Numerous states have refused or delayed extradition to the former Yugoslav countries and Rwanda, sometimes due to the lack of an extradition treaty and in some cases due to impediments such as national statutes of limitation and rules prohibiting extradition of nationals. ${ }^{74}$ In 2006 , despite cooperation treaties, ${ }^{75}$ Guatemala impeded Spanish access to information relating to international crimes committed during the

\footnotetext{
${ }^{71}$ See Eur. Comm'n H.R. Dec. \& Rep., (Plenary), Klaus Altmann (Barbie) v. France, Application No.
} 10689/83, Decision of 4 July 1984 on the admissibility of the application', Decisions and Reports, No. 37, pp. $225-235$.

72 'Ethiopia-South Africa: Mengistu Extradition Request', IRIN, 6 December 1999, available at http://www.irinnews.org/report/11047/ethiopia-south-africa-mengistu-extradition-request, accessed 2 August 2018. See also Bernard Hibbitts, 'No Zimbabwe Extradition Of Mengistu After Ethiopia Genocide Conviction', Jurist, 13 December 2006, available at http://jurist.org/paperchase/2006/12/nozimbabwe-extradition-of-mengistu.php, accessed 2 August 2018.

${ }^{73}$ Richard Galpin, 'Indonesia Rejects Timor Extraditions', BBC News, 19 February 2002, available at http://news.bbc.co.uk/1/hi/world/asia-pacific/1828846.stm, accessed 2 August 2018.

${ }^{74}$ Miljenko Dorić, Explanatory Memorandum, The Obligation of Member and Observer States of The Council of Europe to Co-Operate in the Prosecution of War Crimes, Council of Europe Parliamentary Assembly, 17 December 2010, para. 16-21; African Rights and Redress, Extraditing Genocide Suspects From Europe to Rwanda: Issues and Challenges, 1 July 2008.

\footnotetext{
${ }^{75}$ Extradition Treaty Between Spain and Guatemala, Guatemala, 7 November 1895.
} 
Guatemalan civil war and refused extradition of former officials. ${ }^{76}$ Similarly, Argentina maintained a twenty-year refusal to cooperate with France, Italy and Spain in their attempts to prosecute violations committed by members of the Argentinean military junta. ${ }^{77}$ The Argentinean authorities claimed that foreign courts could not prosecute crimes that had been committed in Argentina due to the principle of territoriality. ${ }^{78}$ Senegal refused numerous Belgian extradition requests for Hissene Habre, despite aut dedere aut judicare and cooperation obligations under the Convention Against Torture. ${ }^{79}$

There have been some trials at national levels. There were a number of prosecutions following the Second World War. However, these were often for "ordinary" crimes under domestic law rather than for international crimes, with jurisdiction exercised on

76 'Arrest Warrants Against Former Military Officials', Rights Action/NISGUA (Network in Solidarity with Guatemala), 12 November 2006; 'Spain Seeks Guatemalan Ex-Rulers', BBC News, 23 December 2006, available at http://news.bbc.co.uk/2/hi/americas/6205327.stm, accessed 5 November 2019.

${ }^{77}$ Roseann M. Latore, 'Coming Out of the Dark: Achieving Justice for Victims of Human Rights Violations by South American Military Regimes', 25 Boston College International and Comparative Law Review (2002) 419-448; Maria Fernandez Perez Solla, 'Enforced Disappearance before Argentinean Tribunals: New Developments in an Endless Fight for Justice', 9 South African Journal on Human Rights (2003) 691-716.

${ }^{78}$ Human Rights Watch, Argentina: Reluctant Partner: The Argentine Government's Failure to Back Trials of Human Rights Violators, December 2001, Part VII; Rebecca Litchfield, 'Accountability in Argentina: 20 Years Later Transitional Justice Maintains Momentum' International Center for Transitional Justice August 2005, p. 5. This is no longer the position in Argentina. See 'Argentina: President Allows Extraditions', New York Times, 26 July 2003.

${ }^{79}$ International Court of Justice, Questions relating to the Obligation to Prosecute or Extradite (Belgium v. Senegal), Judgment, 20 July 2012, I.C.J. Reports 2012, p. 422. 
nationality, territoriality or passive personality grounds. ${ }^{80}$ Prosecutions by third states on the grounds of universality were rare. ${ }^{81}$ The human rights abuses of the cold war regimes went largely unpunished in the states of territoriality at the time. ${ }^{82}$ Attempts by third states to exercise jurisdiction on the grounds of protective and passive personality jurisdiction over torture and enforced disappearance committed by members of foreign regimes amounted, at best, to in absentia convictions. ${ }^{83}$ Following the 1990s conflicts in the former Yugoslavia and Rwanda, some European states undertook trials of those accused of international crimes, who had fled to their territory as a result of the conflicts. In many cases, these states exercised jurisdiction over the crimes concerned under the universality principle, without the traditional territoriality or nationality links to the crimes, the defendant, or the victims. ${ }^{84}$ Yet a number of the legal personnel involved in these prosecutions lament the technical difficulties of accessing information and evidence from other states using traditional judicial cooperation agreements. ${ }^{85}$

\footnotetext{
${ }^{80}$ Alex Marschik, 'The Politics of Prosecution: European National Approaches to War Crimes', in Timothy L.H. McCormack and Gerry Simpson, (eds.), The Law of War Crimes: National and International Approaches, (Kluwer, The Hague, 1997), pp.65-101.

${ }^{81}$ The Eichmann trial was a notable exception. See Attorney General of Israel v. Eichmann, (1968) 36 ILR 5; Attorney General of Israel v. Eichmann, (1968) 36 ILR 227.

${ }^{82}$ Naomi Roht-Arriaza, 'The New Landscape of Transitional Justice', in Naomi Roht-Arriaza and Javier Mariezcurrena, (eds.), Transitional Justice in the Twenty-First Century: Beyond Truth versus Justice, (Cambridge University Press, Cambridge, 2006), pp.1-16, at .3-4.

${ }^{83}$ Amnesty International, Universal Jurisdiction: The Duty of States to Enact and Enforce Legislation, Chapter Two, The History of Universal Jurisdiction, AI Index: IOR 53/004/2001, 1 September 2001.

${ }^{84}$ Reydams, supra note 13, pp.147-157, 220-222.

${ }^{85}$ A Legal Gap? supra note 17; The Global Fight Against Impunity, supra note 17.
} 
It is clear that if states are to assume a more active role in prosecuting international crimes, they require a system of judicial cooperation and extradition tailored to that purpose.

\section{International Law Commission Draft Articles on Crimes Against Humanity}

In 2013, the International Law Commission (ILC) placed the topic of crimes against humanity on its long-term work programme,${ }^{86}$ moving it to its current programme a year later and appointing a Special Rapporteur. ${ }^{87}$ It did so on the basis that: (1) of the three core crimes - genocide, war crimes and crimes against humanity - only crimes against humanity are not the subject of a global treaty requiring states to prevent and punish them and cooperate to that end; (2) crimes against humanity may be more prevalent than either genocide, which requires a specific intent, or war crimes, because they can be committed in situations where there is no armed conflict; and (3) treaties on prevention, punishment and inter-state cooperation exist for far less serious offences. ${ }^{88}$ The conclusion was that 'a global convention on prevention, punishment and inter-State cooperation with respect to crimes against humanity appears to be a key missing piece in the current framework of international law' ${ }^{89}$ The objective for

\footnotetext{
${ }^{86}$ Report of the International Law Commission on the Work of Its Sixty-Fifth Session, U.N. GAOR, 68th Sess., Supp. No. 10, U.N. Doc. A/68/10, at 116, para. 170 and Annex B (2013).

${ }^{87}$ Report of the International Law Commission on the Work of Its Sixty-Sixth Session, U.N. GAOR, 69th Sess., Supp. No. 10, U.N. Doc. A/69/10, at 247, para. 266

${ }^{88}$ International Law Commission, supra note 19, paras. 10-11.

${ }^{89} \mathrm{Ibid}$, para 12.
} 
the ILC was to draft articles for what could become a convention on the prevention and punishment of crimes against humanity. ${ }^{90}$ Despite the inadequacies of the cooperation regimes relating to all three of the core crimes outlined above, and without conducting any meaningful investigation into the effectiveness of the genocide and war crimes cooperation regimes, the ILC dismissed the idea it should undertake work on a more expansive initiative. It stated that genocide and war crimes are 'already the subject of widely-adhered to global treaties relating to their prevention and punishment' and that these could be updated through a new instrument. ${ }^{91}$ Thus, from the outset, the ILC project maintains and indeed reinforces a fragmentation in how inter-state cooperation on prosecuting international crimes will be regulated and exercised. ${ }^{92}$

The Draft Convention has three principal aims: prevention, punishment and interState cooperation. It imposes a general obligation on States Parties to prevent and punish crimes against humanity ${ }^{93}$ through effective legislative, administrative, judicial and other measures. ${ }^{94}$ Crimes against humanity are defined in accordance with Article 7 of the ICC Statute ${ }^{95}$ in light of its wide acceptance by states, in order to minimize fragmentation in international criminal law and to promote the complementarity

\footnotetext{
${ }^{90}$ Ibid, para 13 .

${ }^{91}$ Ibid, para 15. See also Murphy, supra note 24, p.308.

${ }^{92}$ Tladi, supra note 21, p.382.

${ }^{93}$ Draft Article 2.

${ }^{94}$ Draft Article 4.

${ }^{95}$ Draft Article 3.
} 
regime of the ICC. ${ }^{96}$ States parties are required to ensure domestic criminalization of crimes against humanity, ${ }^{97}$ to establish territorial, nationality and passive personality jurisdiction, not excluding the possibility of other criminal jurisdiction under national law, and to ensure that jurisdiction can be exercised when an alleged offender is present on their territory. ${ }^{98}$ An aut dedere aut judicare obligation is included in draft article 10 and stipulates that states parties shall prosecute an alleged offender unless the person is extradited or surrendered to another state or competent international criminal tribunal.

\subsection{Extradition}

Extradition, along with mutual legal assistance, forms one of the lengthiest provisions ${ }^{99}$ of the Draft Convention. This reflects the central role of extradition within the draft Convention, through draft article 7 and the establishment of jurisdiction and draft article 10 on aut dedere aut judicare. Both of these obligations can be discharged through the extradition of the alleged offender to another State for prosecution. Extradition under the draft Convention is largely modeled on the UN

\footnotetext{
96 International Law Commission, supra note 19, para 122; Report of the International Law Commission, Seventy-First Session (29 April-7 June 2019 and 8 July-9 August 2019), (A/74/10), Chapter IV, p.30.

${ }^{97}$ Draft Article 6. For a detailed analysis of this provision see Elies van Sliedregt, 'Criminalization of Crimes Against Humanity under National Law', 16 JICJ (2018) 729-749.

${ }^{98}$ Draft Article 7.

${ }^{99}$ Draft Article 13.
} 
Convention against Corruption (UNCAC) and to a lesser extent the UN Convention on Transnational Organized Crime (UNTOC). The Commentary to the Draft Articles explains that these instruments are relied upon because the issues arising in the context of extradition are largely the same regardless of the underlying crime. ${ }^{100}$ It is true that organized crime, corruption and crimes against humanity share the characteristic of complexity. However, crimes against humanity are arguably more internationally politically contentious and contested than the crimes dealt with under UNTOC and UNCAC. Reliance on UNTOC and UNCAC is further justified on the grounds that these Conventions have large numbers of states parties, states are familiar with their processes, and the language within them has been explained in detailed guides developed by UNODC. ${ }^{101}$ Whether state familiarity is a robust basis for modeling a new treaty on existing provisions must be questioned. ${ }^{102}$

Draft Article 13(1) obliges states to expedite extradition procedures and to simplify evidentiary requirements in relation to extradition requests concerning crimes against humanity. There is no provision on dual criminality. The requirement under draft article 5 to criminalize crimes against humanity under national law means that crimes against humanity will be offences under the laws of both the requesting and requested

\footnotetext{
${ }^{100}$ Report of the International Law Commission, Seventy-First Session (29 April-7 June 2019 and 8 July-9 August 2019), A/74/10, Chapter IV.

${ }^{101}$ International Law Commission, Fourth Report on crimes against humanity by Sean D. Murphy, Special Rapporteur, (A/CN.4/725), 18 February 2019, para. 120.

${ }^{102}$ On this point see comments of Escobar Hernandez in International Law Commission, Sixty-ninth session (first part), Provisions Summary record of the $3350^{\text {th }}$ meeting, (A/CN.4./SR3350), 2 June 2017,
} 3. 
state and dual criminality will therefore be satisfied. ${ }^{103}$ Under Draft Article 13(2) crimes against humanity ${ }^{104}$ are to be deemed extraditable offences in any existing extradition treaty between states and are to be included in any extradition treaties subsequently concluded.

In accordance with evolving practice, ${ }^{105}$ the political offence exception is not permitted as a ground for refusal of extradition between states. ${ }^{106}$ This is to be welcomed as many states in which crimes against humanity have been committed in the past have framed those crimes as "political" within domestic legislation. ${ }^{107}$ Exclusion of the political offence exception removes the possibility of this ground being manipulated as a means of refusing extradition. It ought to be noted, however,

${ }^{103}$ International Law Commission, Third Report on Crimes Against Humanity by Sean D. Murphy, Special Rapporteur, (A/CN.4/704), 23 January 2017, paras. 31-36. See also Commentary to the Draft Articles, in ILC Report, Seventy-First Session, supra note 99, pp.120-121.

${ }^{104}$ To be interpreted as encompassing the crimes of draft articles 3 and 6. See International Law Commission, Sixty-Ninth Session, Statement of the Chairman, 1 June 2017, p 7.

${ }^{105}$ Current treatment of the political offence exception in international law is set out in International Law Commission, Third Report, supra note 103, paras. 42-49. Note also that the statutes of the ad hoc Tribunals do not permit states to refuse to transfer individuals on the basis that the offence concerned is political. Likewise, the ICC Statute does not allow for refusal of requests for surrender on the grounds that the request relates to a political crime.

${ }^{106}$ Draft Article 13(3).

${ }^{107}$ Chile: Supreme Decree No. 355, Creation of the Commission on Truth and Reconciliation, Santiago, 25 April 1990, Art. 1; South Africa: Promotion of National Unity and Reconciliation Act, No. 34 of 1995, Preamble; UN Transitional Administration in East Timor Regulation No. 2001/10 on the Establishment of a Commission for Reception, Truth and Reconciliation in East Timor, UN Doc. UNTAET/REG/2001/10, 12 July 2001, s.3.1(a). 
that while the exclusion accords with much of the academic scholarship, ${ }^{108}$ and was approved by many delegations in the Sixth Committee, others expressed the view that the exclusion is contrary to contemporary extradition practice, suggesting that this may be an issue that has not entirely been settled. ${ }^{109}$

States that make extradition conditional on the existence of a treaty are permitted to use the draft Convention as the legal basis for extradition in the event that they receive a request for extradition from a state with which they have no treaty arrangement in place under Article 13(4). They are to notify the UN Secretary General whether they intend to use the Draft Convention as the legal basis for extradition to and from states with which they have no treaty. ${ }^{110}$ This provision is weaker than in the first version of the draft article on extradition, ${ }^{111}$ which favoured a provision that would have made using the draft Convention as a basis for extradition in the absence of an existing treaty the default position. The Drafting Committee considered it necessary to make this change in order to bring the draft convention in line with the "generally accepted approach" of UNCAC and UNTOC, adding that the

\footnotetext{
${ }^{108}$ Harmen van der Wilt, 'Extradition and Mutual Legal Assistance in the Draft Convention on Crimes Against Humanity', 16 Journal of International Criminal Justice (2018) 795-812, pp.799-801.

${ }^{109}$ International Law Commission, Report of the International Law Commission on the work of its sixty-ninth session (1 May-2 June and 3 July-4 August 2017), (A/72/10). UNGA, Topical summary of the discussion held in the Sixth Committee of the General Assembly during its seventy-second session, prepared by the Secretariat, (A/CN.4/713), 26 February 2018, p.103. See also ILC Fourth Report on Crimes Against Humanity, supra note 101, para. 244.

${ }^{110}$ Draft Article 13(4)(a).

${ }^{111}$ International Law Commission, Third Report on Crimes Against Humanity, supra note 103, Annex, Draft Article 11(4)(a)
} 
amendment would also add clarity for judges in applying and interpreting the instrument. ${ }^{112}$ This author is not convinced of the need to follow the approach of UNCAC and UNTOC in this regard, nor that the alteration provides any additional clarity. Where a state will not use the draft Convention, it is to seek the conclusion of extradition treaties with other states parties. ${ }^{113}$ For those that do not make extradition conditional upon a treaty, crimes against humanity are to be considered extraditable offences. $^{114}$

Draft Articles 13(4) and (5) largely mirror arrangements under Article 44(5) of the UNCAC and Article 16(4) and (5) UNTOC. At first glance, this appears a logical means of plugging the impunity gap as prosecutions of international crimes can be impeded because of the lack of relevant treaties between states. However, recent research demonstrates that UNCAC and UNTOC have rarely been used by states parties as a basis for extradition. Admittedly, it is difficult to obtain comprehensive information on this issue due to the lack of effective reporting and review mechanisms under the treaties. Although the Implementation Review Mechanism for UNCAC has been operational since 2010, there has only been one cycle of review on international cooperation. ${ }^{115}$ The data provided by states shows, however, that they

\footnotetext{
${ }^{112}$ International Law Commission, Sixty-Ninth Session, Statement of the Chairman, 1 June 2017, p.8.

${ }^{113}$ Draft Article 13(4)(b).

${ }^{114}$ Draft Article 13(5).

115 Information on the Implementation Review Mechanism can be found at: http://www.unodc.org/unodc/en/corruption/implementation-review-mechanism.html, $\quad$ accessed 16
} August 2018 . 
generally use bilateral and regional frameworks as the legal bases for extradition ${ }^{116}$ and that few rely on UNCAC in practice. ${ }^{117}$ Reasons for this are varied and include: lack of knowledge among practitioners about the possibility of using the Convention; lack of decision making on using the Convention as a legal basis for extradition among governmental and judicial authorities; and a general preference for using bilateral or regional extradition treaties. ${ }^{118}$ Likewise, although there is as yet no review mechanism in place for UNTOC, ${ }^{119}$ a recent study suggests that little use is being made of UNTOC as a basis for extradition, with states preferring to use regional or bilateral treaties. ${ }^{120}$ This raises questions as to whether the draft Convention is likely to improve the prospects for extradition in the case of crimes against humanity. If states parties to UNTOC and UNCAC continue to prefer to use existing treaties for extradition in relation to corruption and organized crime, there is nothing to suggest that matters should be any different for crimes against humanity. If that is the case,

${ }^{116}$ United Nations Office on Drugs and Crime, State of Implementation of the United Nations Convention against Corruption. Criminalization, law enforcement and international cooperation $\left(2^{\text {nd }}\right.$ edn) (Vienna, 2017), p.197.

${ }^{117}$ Ibid, 204.

${ }^{118} \mathrm{Ibid}, 204-5$.

${ }^{119}$ The need for a review mechanism under UNTOC was acknowledged in 2014. See Conference of the Parties to the United Nations Convention against Transnational Organized Crime, Resolution 7/1, Strengthening the implementation of the United Nations Convention against Transnational Organized Crime and the Protocols thereto, 2014. There is, however, still no agreement between states parties on the form the review mechanisms should take. See 'Divisions Thwart UNTOC review process' Global Initiative Against Transnational Organized Crime, 4 May 2018.

${ }^{120}$ Neil Boister, 'The Cooperation Provisions of the UN Convention against Transnational Organised Crime: A Toolbox Rarely Used?' 16 International Criminal Law Review (2016) 39-70. 
then the draft articles are unlikely to significantly improve the current situation on cooperation in the extradition of suspects.

Draft Article 13(7) provides that extradition shall be subject to the conditions of the national law of the requested State or applicable extradition treaties, including the grounds upon which the requested State may refuse extradition', with the Commentary to any forthcoming Convention outlining acceptable and unacceptable conditions for refusal. ${ }^{121}$ This provision is disappointingly lacking in innovation. As Amnesty International has pointed out, it will enable states to refuse extradition on the grounds often found in national law, such as prohibition of extradition of nationals or ne bis in idem prohibitions, which might also be exploited to protect sham trials. ${ }^{122}$ Some states have also raised concerns about the retention of these barriers. ${ }^{123}$ In response, the Special Rapporteur has reiterated that the overriding obligation of draft article 9 requires that where they do not extradite, states must submit cases to their own prosecuting authorities. ${ }^{124}$ The provision has also been defended as simply reflecting grounds for refusal that are generally accepted in extradition law. ${ }^{125}$ Nonetheless, it is difficult to escape the sense that this provision, without specific limitations, represents a wasted opportunity to create a modern cooperation regime

\footnotetext{
${ }^{121}$ International Law Commission, Sixty-Ninth Session, Statement of the Chairman, 1 June 2017, p 9.

${ }^{122}$ Amnesty International, International Law Commission: Commentary to the Third Report on Crimes Against Humanity, Index: IOR 40/5817/2017, April, p 9-10.

${ }^{123}$ See for example, Argentina's comments on the non-extradition of nationals, ILC Fourth Report supra note 101 , para 250.

${ }^{124}$ Ibid.

${ }^{125}$ Harmen van der Wilt, supra note $108,803$.
} 
around the most serious international crimes that does away with traditional barriers to extradition. ${ }^{126}$

Draft article 13(8) concerns expedition and simplification of procedures. In line with Draft Article 7's requirement to expand jurisdiction, Draft Article 13(9) obliges states which restrict extradition to those on whose territory the alleged offence was committed to alter this practice by 'pretending' that the offences also occurred in the territory of the state that has established jurisdiction. Draft article 13(10) suggests that where extradition of nationals for enforcement of a sentence is prohibited under national law, the state of nationality consider enforcing the sentence itself and draft article 13(11) deal with requests made on impermissible grounds. Draft Article 13(12) is concerned with requests made by states in which the offence occurred and, lastly, Draft Article 13(13) requires requested states to consult with requesting states before refusing requests.

\subsection{Mutual Legal Assistance}

Mutual legal assistance is regulated under Draft Article 14 and an annex to the draft articles. Draft Article 14 regulates cooperation between states when they seek judicial assistance in the investigation and prosecution of crimes against humanity. The annex consists of procedural rules and applies either where there is no existing MLAT

\footnotetext{
${ }^{126}$ Claus Kress and Sevane Garibian, 'Laying the Foundations for a Convention on Crimes Against Humanity: Concluding Observations,', 16 JICJ (2018) 909-957.
} 
between states or where they prefer to use the annex rather than an existing treaty. ${ }^{127}$ States are encouraged - though not required - to apply the annex if it facilitates cooperation. ${ }^{128}$

Under Draft Article 14(1) states are to 'afford each other the widest measure of mutual legal assistance in investigations, prosecutions and judicial proceedings' relating to crimes against humanity. Such assistance is to be provided in respect of offences for which a legal person may be held liable and is not limited to natural legal persons. ${ }^{129}$ The purposes for which mutual legal assistance can be sought are listed in draft Article 14(3) and relate primarily to the collection of evidence and the identification and location of persons of interest. Van der Wilt explains that while many of these are routinely found in MLATs, others, such as assistance in gaining forensic evidence ${ }^{130}$ and identification of victims ${ }^{131}$ are particularly important in prosecutions of international crimes. Assistance is not to be refused on the ground of bank secrecy under draft article 14(4). States are urged to consider the conclusion of additional bi- or multilateral agreements to further the provision of mutual legal assistance in relation to crimes against humanity in draft Article 14(5). They are also permitted, under Article 14(6), to transmit information to another state without prior request, if it is believed that this will assist the other state in undertaking or concluding investigations, prosecutions and other proceedings.

\footnotetext{
${ }^{127}$ Draft Article 14(8).

${ }^{128}$ Ibid.

${ }^{129}$ Draft Article 14(2).

${ }^{130}$ Draft Article 14(3)(e).

${ }^{131}$ Draft Article 14(3)(a)
} 
Draft Article 14(7) provides that the Draft Convention shall not prejudice other treaty obligations. In a previous draft, the provisions of draft article 14 were to apply where they provided for greater mutual legal assistance than existing obligations. However, Germany's claim that this should be rejected because it creates legal uncertainty in light of the priority given to existing arrangements under draft Article 14(2) was followed, ${ }^{132}$ and the phrase 'except that the provisions of this draft article shall apply to the extent that they provide for greater mutual legal assistance" was deleted in the most recent draft. This brings the draft Convention in line with obligations under UNTOC and UNCAC. Yet even before the German objections were raised, Amnesty International had pointed out that some existing treaties require states to refuse assistance on inappropriate grounds, such as pardons, and that these ought to be revised or considered superseded. ${ }^{133}$ Previously, such grounds should not have proved problematic because Article 14 would have become applicable, providing for greater assistance. The result of this revision is that a number of obstructive provisions under existing arrangements will continue to have effect, even where they thwart the provision of assistance. If facilitating cooperation around crimes against humanity is the draft Convention's objective, it might have been better to sacrifice some certainty and familiarity in the interests of maximizing the possibilities for cooperation by removing restrictive grounds for refusal of assistance.

The final section of draft article 14 urges states to consider agreements with international mechanisms established under the UN that have a mandate to collect

${ }^{132}$ ILC Fourth Report, supra note 101, para 268-269.

${ }^{133}$ Amnesty International, supra note 122, p 13. 
evidence of crimes against humanity. ${ }^{134}$ This is intended to fill the gap that exists for some states that require formal frameworks in order to exchange information with a UN established body. ${ }^{135}$

As mentioned, draft Article 14 is complemented by a Draft Annex, which contains a 'mini mutual assistance treaty'. ${ }^{136}$ Paragraph 2 requires states to designate a central authority to receive and process requests for assistance. There is no requirement, or indeed encouragement, to designate law enforcement officials as the central authority in an effort to ensure independence and impartiality in decisions on requests for assistance. Instead, the diplomatic, political channels still used by a number of states can be retained. ${ }^{137}$ Paragraphs 3 and 4 set out the format for making requests, paragraph 5 allows for requests for supplemental information, and paragraphs 6 and 7 regulate responses by the requested state, emphasizing the need for timely execution.

Under paragraph 8 , requests may be refused, with reasons, ${ }^{138}$ on a number of grounds, including where the requested state considers that execution of the request is likely to prejudice its sovereignty, security, ordre public or other essential interests. These grounds are routine across existing MLATs, and will therefore continue to apply in many cases where states rely on existing arrangements. It is, however, disappointing

\footnotetext{
${ }^{134}$ Draft Article 14(9). This follows a proposal by the UN Office on Genocide Prevention and the Responsibility to Protect.

135 ILC Fourth Report, supra note 101, para. 272.

${ }^{136}$ See International Law Commission, Sixty-Ninth Session, Statement of the Chairman, 1 June 2017, p.10.

${ }^{137}$ Amnesty International, supra note 122, p.14.

${ }^{138}$ Paragraph 9.
} 
to see them replicated here, given their legal ambiguity and their propensity to exploitation by states reluctant to cooperate. While international criminal law no longer accepts unilateral assertions of national sovereignty ${ }^{139}$ or national security as grounds for refusing assistance to international courts, ${ }^{140}$ inter-state assistance in cases involving serious human rights violations has often been refused on these grounds. ${ }^{141}$ The breadth of information covered by 'national security' and the ease with which states can classify categories of information as relating to it ${ }^{142}$ makes this an easy means of avoiding assistance for a state that is unwilling to provide judicial assistance. The ground of threats to public order is similarly open to exploitation. It has been suggested that this ground is rarely invoked and serves only as a protection in principle for states. ${ }^{143}$ However, in states that have experienced crimes against

${ }^{139}$ See ICTY, Prosecutor v. Blaskic, Case No. IT-95-14-AR108BIS, Judgment on the Request of the Republic of Croatia for Review of the Decision of Trial Chamber II of 18 July 1997, 29 October 1997, para. 65; ICTR, Prosecutor v. Kanyabashi, Case No. ICTR-96-15-T, Judgment of the Defence Motion on Jurisdiction, 18 June 1997. See also Salavatore Zappala, 'Blaskic Subpoena Proceedings', in Antonio Cassese (ed.), The Oxford Companion to International Criminal Justice, (Oxford University Press, Oxford, 2009), pp.613-615

${ }^{140}$ ICC Statute, Art. 72.

${ }^{141}$ Alison Bisset, 'Truth Commissions: A Barrier to the Provision of Judicial Assistance?' 10 International Criminal Law Review (2010) 647-678.

${ }^{142}$ David Banisar, 'Freedom of Information, International Trends and National Security', Geneva Centre for the Democratic Control of Armed Forces, October 2002; Campbell Public Affairs Institute (ed.), National Security and Open Government: Striking the Right Balance, (Campbell Public Affairs Institute, New York, 2003), 75-101.

${ }^{143}$ Kimberly Prost, 'Toward Meaningful Adherence to Multilateral Instruments for Meaningful Cooperation: The Challenges to Effective Mutual Legal Assistance' in Rodrigo Yepes-Enriquez and Lisa Tabassi (eds.), Treaty Enforcement and International Cooperation in Criminal Matters with 
humanity, the threat posed by criminal prosecutions to peace and stability is often advanced as an argument against pursuing trials. ${ }^{144}$ Such fears may be legitimate or may be fabrications to avoid criminal accountability. Nevertheless, the availability of this ground for refusal provides an uncooperative state with legally permissible grounds for refusing assistance.

The inclusion of these 'vague and subjective' grounds for refusal has been strongly criticized as one of the main problems under the current legal framework, the retention of which are likely to prove counterproductive in a treaty designed to improve state cooperation in relation to crimes against humanity. ${ }^{145}$ The ILC has been urged to reconsider this provision and adopt the 'more circumscribed' language of Article 93(3) of the ICC Statute. ${ }^{146}$ This obliges states to consult with the Court, where execution of requests are prevented by national laws, in order to resolve the matter and in an effort to find alternative means of providing assistance. Ironically, however, even in light of requests from states themselves for greater clarity on these 'indeterminate legal concepts', the ILC has remained unshakeable in its stance that

Special Reference to the Chemical Weapons Convention (TMC Asser Press, The Hague, 2002) pp.480$491,484$.

${ }^{144}$ Alison Bisset, Truth Commissions and Criminal Courts, (Cambridge University Press, Cambridge, 2012), pp.162-164.

${ }^{145}$ Amnesty International, supra note 122, p 15; War Crimes Committee of the International Bar Association, Comments on the International Law Commission's Draft Articles in Crimes Against Humanity, November 2018, p12.

${ }^{146}$ Kress and Garibian, supra note 126. 
adherence to the existing and familiar language of UNTOC and UNCAC is desirable on the grounds of legal certainty. ${ }^{147}$

Although not a ground for refusal, paragraph 10 permits the requested state to postpone mutual legal assistance where it interferes with an ongoing investigation, prosecution or judicial proceeding. The question of whether national level initiatives such as amnesty schemes and truth seeking mechanisms might prevent - or be used to impede - the provision of mutual legal assistance has been raised previously. ${ }^{148}$ It has been suggested that paragraph 10 should have a timeliness phrase imposed in relation to the length of time a requested state can delay the provision of assistance in order to mitigate the risk of indefinite delays where the requested state is either unable or unwilling to provide assistance. ${ }^{149}$ This has not been incorporated within the most recent version of the draft Convention. However, this would not resolve the issue of whether a national amnesty law might prevent the provision of assistance in certain circumstances, for instance if the requested, amnesty granting state considers that security, public order or other interests might be jeopardized if it were to provide assistance to a state that might potentially prosecute an individual already granted amnesty. Indeed, the wider and contentious question of amnesties remains unsettled within the draft Convention. ${ }^{150}$ The ILC has stated that an amnesty by one state will

\footnotetext{
${ }^{147}$ ILC Fourth Report, supra note 101, para 291.

${ }^{148}$ Bisset, supra note 141.

${ }^{149}$ International Bar Association, supra note 145, p12.

${ }^{150}$ ILC Fourth Report, supra note 101, paras. 302-305. Sarah M.H. Nouwen 'Is There Something Missing in the Proposed Convention on Crimes Against Humanity? A Political Question for States and a Doctrinal One for the International Law Commission', 16 JICJ (2018) 877-908; Hugo A. Relva,
} 
not prevent prosecution by another with jurisdiction and that any amnesty would need to be evaluated in light of a state's treaty obligations. However, the ILC has stopped short of prohibiting amnesties, justifying its silence, once again, on the ground that other treaties are similarly quiet. ${ }^{151}$

Beyond this, the Draft Annex contains little of controversy. Paragraph 13 covers purpose limitation, paragraph 14 concerns confidentiality surrounding requests, and paragraph 15 ensures "safe conduct' for witnesses, experts and others who assist in investigations or proceedings in the requesting state. Paragraphs 17-19 then regulate the transfer for the purposes of testimony or identification of persons of those detained or serving sentences in the requested state. All of these provisions are routinely contained within MLATs.

Yet one of the biggest impediments to inter-state cooperation and the exercise of extra-territorial jurisdiction - the immunities enjoyed by incumbent heads of state and other high ranking state officials - remains a murky area within the ILC Draft Convention. Draft Article 6(5) prohibits reliance on the holding of an official position as a ground for excluding criminal responsibility, but the commentaries to draft Article 6 state that this 'has no effect on any procedural immunity that a foreign State official may enjoy before a national criminal jurisdiction'. ${ }^{152}$ While there is some

\footnotetext{
'Three Propositions for a Future Convention on Crimes Against Humanity: The Prohibition on Amnesties, Military Courts, and Reservations’ 16 JICJ (2018) 857-875.

${ }^{151}$ Report of the Commission on the work of its sixty-ninth session, Official Records of the General Assembly, Seventy-first session, Supplement No. 10 (A/72/10), para. 46; Commentary to draft articles 10, para. 11.

${ }^{152}$ ILC Third Report, supra note 103, at 69.
} 
reluctant acceptance that the introduction of a treaty based waiver of immunities ratione personae would have been politically impossible, ${ }^{153}$ the ILC's failure to address the issue of immunity ratione materiae has been strongly criticised. ${ }^{154} \mathrm{~A}$ full discussion of immunities is outside the scope of this article, but as Kress and Garibian explain, 'the real practical impact of the future Convention is intimately connected with the immunity question'. ${ }^{155}$

In sum, the cooperation aspects of the ILC Draft Convention are conservative, with much copied over from existing arrangements. While this might be perceived as a strength, with familiarity enhancing the prospects for gaining the acceptance of states, it is also likely to be its downfall. The retention of traditional grounds for refusing assistance makes withholding cooperation easy. The failure to incorporate a more innovative system of cooperation, abolishing traditional grounds, and the absence of scrutiny mechanisms that might make refusal more difficult is one of the most disappointing aspects of the draft Convention. The ILC cannot be unaware of the ways in which states have sought to withhold cooperation in the past and how existing mechanisms enable that. While no Convention will stop the truly uncooperative state, the possibilities for 'legal' hampering should have been restricted in the new convention, even if this requires countries to grapple with a new system of inter-state cooperation. States are already adept at utilising multiple cooperation systems as those applicable in the relationship between states and international courts differ from

\footnotetext{
153 Kress and Garibian, supra note 126, at 939-40.

${ }^{154}$ Micaela Frulli, 'The Draft Articles on Crimes Against Humanity and Immunities: Unfinished Business?' 16 JICJ (2018) 775-793.

155 Kress and Garibian, supra note 126, at 939.
} 
the inter-state system. Indeed, it is a pity that the ILC did not take the opportunity to bring inter-state cooperation arrangements in line with international criminal law standards on grounds for refusing assistance when it comes to the international crime of crimes against humanity.

\section{The Mutual Legal Assistance Treaty for Core Crimes}

Separate from the ILC's development of the Draft Articles, a 'core group of states ${ }^{\text {' }} 156$ has been working on a treaty that would enhance mutual legal assistance in the investigation and prosecution of all three core crimes. ${ }^{157}$ The Mutual Legal Assistance Initiative is premised on the idea that the inadequacies of narrow and outdated existing inter-state cooperation arrangements relating to core crimes are one of the biggest impediments to ending impunity and that a robust and effective model of state cooperation is needed to facilitate mutual legal assistance and extradition. The Initiative was therefore envisaged as a means of rapidly operationalising an effective, inter-state cooperation regime relating to genocide, crimes against humanity and war

\footnotetext{
${ }^{156}$ The original core group consisted of Belgium, the Netherlands and Slovenia, later expanding to include Argentina, Mongolia and Senegal. See Declaration on International Initiative for Opening Negotiations on a Multilateral Treaty for Mutual Legal Assistance and Extradition in Domestic Prosecution of Atrocity Crimes (crimes of genocide, crimes against humanity and war crimes) (on file with author).

${ }^{157}$ A summary of the development of this initiative can be found in ILC Fourth Report, supra note 101, paras 318-325.
} 
crimes. ${ }^{158}$ Since its initial conception, the Initiative has attracted the support of over 60 states. $^{159}$ In December 2018, a 66 article draft Convention on International Cooperation in the Investigation and Prosecution of the Crime of Genocide, Crimes Against Humanity and War Crimes (the MLA Treaty) was finalised. ${ }^{160}$ It covers not only mutual legal assistance ${ }^{161}$ and extradition, ${ }^{162}$ but definitions of core crimes, ${ }^{163}$ protection of sovereignty, ${ }^{164}$ criminalization in domestic law, ${ }^{165}$ establishment of jurisdiction, ${ }^{166}$ preliminary inquiry, ${ }^{167}$ liability of legal persons, ${ }^{168}$ transfer of persons sentenced, ${ }^{169}$ and issues surrounding experts and witnesses. ${ }^{170}$ As in the ILC Draft Articles, the aut dedere aut judicare, ${ }^{171}$ obligation is a key component of the MLA Treaty. Of note is that unlike in the ILC draft Articles, the aut dedere aut judicare

${ }^{158}$ Advisory Committee on Issues of Public International Law, Advisory Report on the ILC Draft Articles on Crimes Against Humanity, The Hague, August 2018, 1-2.

${ }^{159}$ ILC Draft Articles on Crimes Against Humanity - Comments and Observations of the Kingdom of the Netherlands, para 9.

${ }^{160}$ Convention on International Cooperation in the Investigation and Prosecution of the Crime of Genocide, Crimes Against Humanity and War Crimes, annexed to ILC Draft Articles on Crimes Against Humanity - Comments and Observations of the Kingdom of the Netherlands.

${ }^{161}$ Articles 15-30.

162 Articles 31-41.

${ }^{163}$ Article 2.

${ }^{164}$ Article 3 .

165 Article 4.

${ }^{166}$ Article 5.

${ }^{167}$ Article 6.

${ }^{168}$ Article 8.

${ }^{169}$ Articles 42-55.

${ }^{170}$ Articles 56-57.

${ }^{171}$ Article 7. 
obligation is not discharged under the MLA Treaty by surrendering an alleged offender to an international criminal tribunal, something which seems a peculiar omission given the central role that international courts have played in the prosecution of such crimes to date.

From a cooperation perspective, the MLA Treaty initially appears significantly more detailed than the ILC draft Articles. On extradition, it includes provisions on conditional extradition, provisional arrest, and transit, which are not included in the ILC Convention. It also contains more detail on the formalities and procedures of requests, presumably because while the ILC Convention assumes reliance on existing arrangements between states, the MLA Treaty works on the basis that states parties will use the Convention as the basis for judicial cooperation. A number of mandatory grounds for refusal are included, which is not the case in the ILC Convention, and states must refuse assistance where there are substantial grounds for believing that the request has been made for the purpose of prosecuting or punishing a person on account of sex, race, religion, nationality, ethnic origin or political opinions or that compliance with the request would cause prejudice to that person's position for any one of these reasons; where there is a possibility of imposition of the death penalty; where the requested state has already made a final judgment against the sought person in relation to the facts for which extradition is sought; and where there is a possibility of torture or other cruel, inhuman or humiliating treatment or punishment in the requesting state. ${ }^{172}$ The third ground, under which extradition must be refused where final judgment has been rendered, again raises questions on the status of national amnesty schemes and other non- or quasi- judicial post-conflict mechanisms. In

\footnotetext{
172 Article 33.
} 
particular, it is unclear whether states that have decided to pursue non-prosecutorial avenues might be able to legitimately refuse extradition on the ground that, for example, a grant of amnesty, is considered the 'final judgment' in a particular case at the national level. The language of 'final judgment' taken with the MLA Treaty's object and purpose of strengthening the prospects for prosecution, might suggest the need for formal legal proceedings to have taken place. Nevertheless, the wording is vague and open to interpretation. ${ }^{173}$

More surprising is that Art 52 of the MLA Treaty permits states, apparently without qualification, to grant pardon, amnesty or commutation of sentence to sentenced persons who have been transferred to serve the sentence imposed. This seems startling given the prohibition under customary law of amnesty for international crimes. ${ }^{174}$ Much of Part V of the MLA Treaty is borrowed from the 1983 Convention on the Transfer of Sentenced Persons, which aims to facilitate transfer of foreign nationals in ordinary criminal cases, rather than in cases involving international crimes. The inclusion of this provision perhaps speaks to the dangers of 'over-borrowing' from familiar but different legal regimes, something that seems to have hindered both the ILC and group of core states in their efforts to create regimes that might truly enhance judicial cooperation in this area.

Like the ILC Draft Convention, it seems probable that the MLA Treaty regime will struggle with practical obstacles around immunities. Unlike the ILC Draft Convention, however, the drafters of the MLA Treaty have not seen fit to include

\footnotetext{
${ }^{173}$ On these issues see Bisset, supra note 144, pp.178-182.

${ }^{174}$ OHCHR, Rule of Law Tools for Post-Conflict States: Amnesties, New York and Geneva, 2009.
} 
provisions either on the impact of official position upon criminal responsibility or on the status of immunities. Given the connection between immunity and cooperation and the potential impact of the law on immunity upon the effectiveness of any new treaty, its omission seems like an oversight.

In essence, however, as the table below illustrates, the extradition provisions of the two treaties are very similar.

[Table 2]

On mutual legal assistance, the MLA Treaty includes provisions on confiscation, ${ }^{175}$ proceeds of crime, ${ }^{176}$ joint investigations ${ }^{177}$ and special investigative techniques, ${ }^{178}$ which the ILC Convention does not contain. It lists twelve types of assistance for which requests can be made, in comparison with the ILC's ten, including additionally recovery of assets, ${ }^{179}$ establishment of joint investigation teams ${ }^{180}$ and the use of special investigative techniques ${ }^{181}$ The ILC includes the identification and locations of alleged offenders, victims and witnesses, which the MLA Treaty does not. ${ }^{182}$ In practical terms there is little difference as both Conventions permit the seeking of any

\footnotetext{
175 Article 21.

${ }^{176}$ Article 22.

177 Article 29.

${ }^{178}$ Article 30.

${ }^{179}$ Article 16(k).

${ }^{180}$ Article 16(h).

${ }^{181}$ Article 16(g).

${ }^{182}$ Article 14(3)(a).
} 
type of assistance not listed that is not contrary to the domestic law of the requested state. ${ }^{183}$ Procedures for making requests are also comparable ${ }^{184}$

Although, on the face of it, the MLA Treaty appears to deal in more depth with judicial assistance, the key difference is really that it situates the detail on MLA within the Convention itself, while the ILC's more detailed provisions are contained within an annex to the main Convention and only applicable where states do not have an existing agreement in place or choose to use the annex. The table below again shows the similarity between the two on mutual legal assistance.

[Table 1]

Overall, the nature and tone of the draft Conventions are largely the same on mutual legal assistance, as the MLA Treaty also borrows heavily from UNTOC and UNCAC. There is therefore little to contrast. The result is that many of the frustrating aspects of the ILC Convention are mirrored in that of the core group of states. Like the ILC, the MLA Treaty requires the designation of a central authority for the issuing and receiving of requests, ${ }^{185}$ but it too leaves the possibility of reliance upon diplomatic channels, ${ }^{186}$ rather than taking the opportunity to curtail the potential for politicization of requests for assistance. It retains the traditional grounds for refusal of assistance, ${ }^{187}$ despite the fact, as discussed above, that retention of those grounds may significantly

\footnotetext{
${ }^{183}$ Article 16(1); ILC Draft Articles, Article 14(3)(j).

${ }^{184}$ Article 17; ILC Draft Articles, Annex, paras 3 and 4.

${ }^{185}$ Articles 12 and 13.

${ }^{186}$ Article 13(2).

${ }^{187}$ Article 19.
} 
impact the effectiveness of inter-state cooperation, as they have in the past. Questions around the impact of amnesty laws and the status of non-judicial investigatory mechanisms vis-à-vis requests for cooperation remain unsettled. Like the ILC Draft Convention, the MLA Treaty permits postponement of assistance where it would interfere with an ongoing investigation ${ }^{188}$ but offers no clarification of what might constitute an 'investigation' and whether it must be linked to formal legal proceedings for the purposes of postponement.

Judicial cooperation is not the only area in which the MLA Treaty overlaps the content of the ILC Convention, a matter that appears to have caused a deal of consternation at the ILC. ${ }^{189}$ Indeed, the fourth report of the Special Rapporteur contains a table illustrating the significant overlap between the two. ${ }^{190}$ The ILC has made the - not unreasonable - point that while some issues considered by the ILC are not considered by the core group of states, and vice versa, the only real difference is that the ILC considers only crimes against humanity, whereas the MLA Treaty additionally includes genocide and war crimes. ${ }^{191}$ It is not difficult to see why the ILC should be concerned by what essentially amounts to a duplication of Conventions aimed at prosecuting core crimes. What is difficult to understand is why the two bodies continued with two distinct projects which cover much of the same material but which, if adopted, would create two different legal regimes on some of the same issues. The ILC seems to point the finger of blame for this towards the core group of

\footnotetext{
188 Article 20(4).

${ }^{189}$ ILC Fourth Report, supra note 101, paras 323-331.

${ }^{190}$ Ibid, 124-5.

${ }^{191}$ Ibid, para. 330.
} 
states. ${ }^{192}$ Yet, it is the ILC's narrow focus and failure to appreciate and acknowledge the wholly inadequate arrangements around genocide and war crimes that have led directly to this situation. It remains something of a mystery as to why the ILC decided to focus solely on crimes against humanity when, in practice, the impediments to justice created by existing cooperation arrangements apply equally to genocide and war crimes.

\section{The Way Forward}

It is undoubtedly the case that crimes against humanity should be the subject matter of a distinct convention in the same way as genocide and war crimes. This has been argued, convincingly, over many years. ${ }^{193}$ However, new, focused and robust interstate cooperation arrangements are needed for all core crimes if national courts are to assume the front line role that they ought to occupy in the consistent and effective prosecution of international crimes. Neither the ILC Convention nor the MLA Treaty achieves this. There is nothing revolutionary or even evolutionary on cooperation within these Conventions; they simply replicate existing provisions and therefore the existing problems around politicization and the ability to thwart cooperation through the exploitation of vague grounds for refusing assistance. Neither body appears to have heeded the warning that simply transposing existing regimes that were not

\footnotetext{
${ }^{192}$ Ibid, 330-331.

${ }^{193}$ Leila Nadya Sadat, (ed.), Forging a Convention for Crimes Against Humanity, (Cambridge University Press, Cambridge, 2011).
} 
created to address the specific context and nature of crimes against humanity may prove ineffective. ${ }^{194}$

The ILC leaves the issues around inter-state cooperation on genocide and war crimes entirely unaddressed. The MLA Treaty is an improvement on the ILC Convention in that it addresses all three core crimes and attempts at least to consolidate a cooperation regime that pertains to all three. However, neither has truly tackled nor rectified the fundamental problems of potential politicization and legally permitted loopholes within current cooperation regimes. Those gaps remain unplugged.

Beyond the missed opportunities on judicial cooperation, there are some pressing and difficult issues on practicalities. The MLA treaty has no clear mechanism in place for state ratification. It was initially introduced via the ICC Assembly of States Parties, a factor that may diminish its attractiveness among some states. It was not deemed appropriate for the Commission on Crime Prevention and Criminal Justice (CCPCJ) of the UNODC, as many states considered that this initiative did not fall within the CCPCJ's mandate. ${ }^{195}$ It is not therefore clear how and via which route states might commit to the MLA Treaty.

In contrast, the ILC Convention may soon be open for ratification and seems likely to be ratified by a large number of states. It has the advantages of having been concluded under the auspices of the ILC, with involvement of all states, something that the MLA

\footnotetext{
${ }^{194}$ Statement at the UN GA $6{ }^{\text {th }}$ Committee, UN Doc. A/C.6/72/SR.18, 23 October 2017.

${ }^{195}$ CCPCJ, International cooperation in the fight against the crime of genocide, crimes against humanity and war crimes (E/CN.15/2013/L.5), para. 1.
} 
Treaty cannot claim. However, it cannot be considered either desirable or sensible to open the ILC Convention for ratification without first giving proper consideration to the likely consequences of overlapping treaties on crimes against humanity. Both entities have been well aware of the work of the other. Yet in approaches that can only be considered woefully blinkered, neither appears to have undertaken meaningful analysis of what the existence of two treaties on crimes against humanity might mean for states parties in practice. Vague statements on 'mutual reinforcement' and the desire that neither adversely affect the other have emerged from various members of the group of core states. ${ }^{196}$ It is, however, the ILC Special Rapporteur's assessment that two treaties are likely to be "inefficient... confusing and risk[s] the possibility that neither succeeds" 197 that seems to capture the most likely outcome of two separate instruments. ${ }^{198}$ The Special Rapporteur's 2019 report passes decision making on how to proceed to states. Thus, the opportunity to create a modern, innovative legal regime for all three core crimes that focuses on their unique nature and removes the legal inventions that have long enabled states to avoid cooperation has not yet passed. Whether states can seize that opportunity remains to be seen.

\footnotetext{
${ }^{196}$ ILC Fourth Report, supra note 101, para 327. See more recently, Sixth Committee Continues International Law Commission Review, Debating Need for Treaty of Crimes Against Humanity, Meetings Coverage, GA/L/3606, 29 October 2019.

${ }^{197}$ ILC Fourth Report, supra note 101, para 331.

${ }^{198}$ See too concerns raised on this issue by Madaline George, 'Prospects for a Convention on the Prevention and Punishment of Crimes against Humanity', OpinioJuris, 8 October 2019, available www.opiniojuris.org (access 5 November 2019).
} 
